\title{
Cuerpo, conyugalidad y mesa común: Símbolos de comunión en las sagradas escrituras
}

\author{
JUAN AlBERTO CASAs RAMÍREZ* \\ Pontificia Universidad Javeriana (Colombia) \\ jcasas.smsj@javeriana.edu.co
}

\begin{abstract}
Resumen
Desde una visión de fe, la comunión supone la posibilidad de que la existencia criatural participe, por la gracia, de la comunión divina trinitaria. El presente artículo, ubicado en el ámbito de la teología bíblica, busca aportar a la reflexión teológica sistemática a través del rastreo sobre el modo como "la realidad comunional" ha sido percibida, comprendida y expresada por parte del hombre bíblico por medio del recurso a imágenes tomadas de su experiencia histórica y cotidiana. Tales imágenes son, principalmente, la unidad orgánica del cuerpo (vegetal y humano), la unión esponsal y la mesa compartida.

Palabras clave: Teología de la comunión, Comunión, Koinonía, Cuerpo, Conyugalidad, Esponsalidad, Mesa común.
\end{abstract}

\section{Body, Spousal union, and Shared table: Symbols of Communion in the Sacred Scriptures}

\begin{abstract}
From a faith perspective, communion supposes the possibility that the existence of the creature could be part, through the grace, of Trinitarian divine communion. This article, located in the field of the biblical theology, seeks to contribute to the systematic theological reflection by probing about the way as the "reality of communion" has been perceived, understood, and expressed by the biblical man using images taken from historical and everyday experience. Such images are, mainly, the organic unity of the body (plant and human), the spousal union, and the shared table.
\end{abstract}

Key words: Theology of Communion, Communion, Koinonia, Body, Spousal Union, Shared table.

* Doctor en Teología, Magíster en Teología y Licenciado en Ciencias Religiosas de la Pontificia Universidad Javeriana, Bogotá-Colombia. Profesor e investigador en el área de Teología Bíblica, Facultad de Teología, de la misma Universidad. Miembro de la Society of Biblical Literature y del grupo de investigación Didaskalia. Publicaciones recientes: "Effatha: Aproximación exegética al relato de curación del tartamudo sordo en Mc 7,3137" (2016); "Entre la oscuridad y el silencio: Ciegos y sordomudos en el mundo de la Biblia" (2016); "Parábolas que siembran ceguera: Repercusiones del lógion de Mc 4,1112 en la interpretación de la "parábola de la siembra" de Mc 4,1-20" (2015); "La conversión como condición de posibilidad del seguimiento del Señor a partir del evangelio de Marcos” (2013). 


\section{INTRODUCCIÓN}

Si existe un rasgo transversal y reiterativo en la reflexión eclesiológica surgida a partir del Concilio Ecuménico Vaticano II (2013) ha sido la consideración de la Iglesia como un misterio de comunión ${ }^{1}$. De hecho, la comunión es una característica esencial del cristianismo y un motivo constitutivo de la reflexión teológica, desde la antropología teológica hasta la teología trinitaria (Zizioulas, 2009) pasando por la teología fundamental (Barrios, 2013), la patrología (Molac, 2009), la teología sacramental (Aldazábal, 2000), la cristología (Albado et al, 2016), la eclesiología (Ponce Cuéllar, 2011; Tejerina Arias, 2015), la teología moral (Serreti, 1997; Sánchez Cañizares, 2014) y la escatología (Ponce Cuéllar, 2013). El presente escrito, ubicado en el ámbito de la teología bíblica, más allá de pretender desarrollar alguna novedad de carácter exegético, busca aportar a dicha reflexión a través del rastreo enunciativo de los campos semánticos transversales en torno al modo como la "realidad comunional" 2 ha sido percibida, comprendida y expresada por parte del hombre bíblico mediante el recurso a imágenes y símbolos tomados de su experiencia histórica y cotidiana; ello teniendo como criterio rector el principio de unidad de toda la escritura.

En tal sentido, es necesario aseverar, en primer lugar, que en el mundo de la Biblia la noción de comunión, además de referirse a una relación de permanente unión entre los miembros involucrados en la misma (como participación recíproca en la vida, en los bienes, en la esperanza y en la fe, incluyendo el destino último de la vida), presupone una posición de igualdad entre dichos miembros que pueda garantizar la reciprocidad de tal unión. Es por esta razón que en el Antiguo Testamento resulta extraña la idea de una comunión entre YHWH y sus criaturas (incluso con el pueblo de Israel) ya que esta afectaría la afirmación confesional, más vinculada a tradiciones sacerdotales, de la trascendencia de aquel y la disposición de obediencia incondicional (y por tanto de subordinación) que se espera de aquellas con respecto a aquel. De hecho, en el Texto Masorético no se

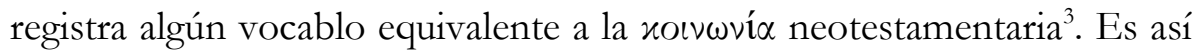

1 LG 4,8,13-15,18,21,24-25; DV 10; GS 32; UR 2-4,14-15,17-19,22; véase también: Congregación para la Doctrina de la Fe (1992); V Conferencia General del Episcopado Latinoamericano y del Caribe (2010: n. 109-110, 129; 154-239).

2 Si bien el sustantivo adjetivado "comunional" no es reconocido por la Real Academia de la Lengua, su uso en teología, para expresar el campo semántico de la comunión, ya ha sido previamente usado en algunas publicaciones en castellano. Así, por ejemplo, Serreti (1997) y Zizioulas (2009).

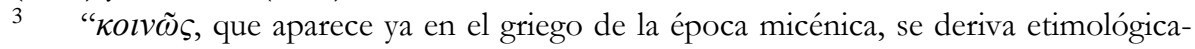
mente de com-yos = el que va junto (lat. cum) y, referido a cosas, significa: común, colectivo, público. De ahí proviene tò xoıvòv, la comunidad, el bien común, y el plural: los asuntos públicos, 
que autores como Hauck (2002: 348-349) señalan que "en el AT los justos dependen de Dios y confían en él, pero no se consideran sus compañeros (...). [Por ello] prevalece un sentido de distancia más que de asociación, incluso cuando hay una experiencia teofánica". Y si bien, el código sacerdotal prescribe un sacrificio llamado "de comunión” (שֶֶׁ) (ver Lv 3,1-17; 7,11-15), este tiene un sentido de acción de gracias, de "inmolación del sacrificio de clausura", e incluso, de compartir festivamente el alimento con Dios, más que de participación en su misma naturaleza (Mora, 2007: $85)^{4}$.

Con todo, es posible afirmar que, de modo progresivo, a lo largo de las Sagradas Escrituras la comunión es prefigurada y presentada como una realidad de origen antropológico con implicaciones teológicas que remite al proyecto salvífico de unión recíproca y auto-donación amorosa entre dos o más seres personales con miras a la conformación de una comunidad de fe y de vida. En dicho sentido, la comunión constituye un eje transversal de toda la tradición bíblica y se expresa, más que a través de nociones o definiciones de carácter noético, por medio de imágenes (metáforas, alegorías, símiles) tomadas de la experiencia cotidiana del pueblo, tal como lo indica Mateos (1982: 259): En la tradición bíblica, "el uso de símbolos pertenece al estilo de la época, cuya teología no se expresaba en conceptos sino en símbolos e imágenes”. Por su parte, Andiñach (2014: 58) afirma que

el estado (...). En el mundo griego y helenístico, koinonía designa la comunión natural, inquebrantable, entre los dioses y los hombres. El mismo Filón (Vit. Mois. I \158) habla "de la sublime comunión (de Moisés) con el Padre y Creador del universo», mientras que en los LXX este término no es utilizado para designar la relación entre Dios y el hombre"

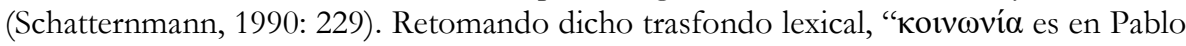
una designación de diversas relaciones comunitarias que surgen por la (común) participación y que se constituyen como una acción (recíproca) de dar participación o de tener participación. Si la relación comunitaria (de la participación común en algo) se comunica por medio de alguien (por ejemplo, Jerusalén, apóstol, maestro), entonces surge una relación deudora que obliga a quien recibe participación a responder haciéndose a su vez partícipe. Es ese caso son xotvwvoì las personas que están en relación de comunión, porque tienen participación común en algo" (Hainz, 2001: 2363).

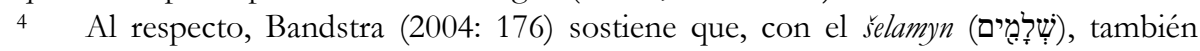
llamado "sacrificio de paz", una porción de la carne del animal sacrificado era mantenida y comida por la persona que hacía el sacrificio (el sacerdote). Esta ofrenda fue llamada también "sacrificio de comunión" porque todos quienes lo presenciaban, incluyendo Dios, participaban de una comida festiva. La carne no era consumida de forma frecuente en los tiempos bíblicos; por ello, cuando se comía, era una oportunidad de celebración realizada en la presencia de Dios. De este modo, se expresaba la comunidad de vida, la relación de alianza y de amistad entre el fiel y su Dios. 
El símbolo es el actor privilegiado en los discursos que presentan lo sagrado. El recurso al símbolo es inevitable, porque todo discurso que emana de la experiencia de fe debe referir a esferas que no siempre admiten la descripción llana de las palabras. Ellos nos remiten a realidades que, de otra manera, sería imposible de nombrar. Pero es notable constatar que el discurso religioso no crea nuevas palabras para expresar realidades que no están presentes en el vocabulario habitual (...). El hecho de resignificar palabras ya existentes dándoles un valor diferenciado tiene una explicación en el proceso de elaboración de la experiencia de fe. La percepción de Dios en la vida y en la historia se efectúa en medio de las experiencias cotidianas, no fuera de ellas (...). La experiencia de fe presente en las Escrituras percibe la acción de Dios en medio de los actos cotidianos y busca expresarla con las mismas palabras regulares, pero cargándolas con un plus de sentido. Al obrarse de esa manera, esa palabra deviene en símbolo.

En efecto, a lo largo del canon, las imágenes que encarnan simbólicamente la realidad comunional han sido tomadas de un trasfondo netamente antropológico y cultural y corresponden, principalmente, a la unidad orgánica del cuerpo (tanto vegetal como humano), la unión esponsal y el compartir de mesa.

\section{LA UNIDAD ORGÁNICA DEL CUERPO (VEGETAL Y HUMANO) COMO SÍM-} BOLO DE COMUNIÓN

1.1. Comunión que es arraigo, permanencia y fructificación: La organicidad vegetal como imagen de la relación vital entre Dios e Israel

Una de las imágenes que precede y fundamenta el motivo de la comunión corporativa, a través de la cual el Antiguo Testamento ha querido simbolizar la relación vital entre Dios y el pueblo, ha sido la alegoría vegetal, muy comprensible en el contexto de una sociedad predominantemente agrícola. Así, en el Salmo 1, el hombre dichoso es aquel que "se recrea en la Ley de YHWH" (es decir, la Torah), "susurrando su ley día y noche" $(\text { Sal 1,2) })^{5}$ Y su relación con la Torah (explicitación de la voluntad de Dios) se equipara "al árbol plantado entre corrientes de agua, que da a su tiempo el fruto y jamás se marchita su follaje" (v.3). De este modo, a diferencia de los impíos, que "son como paja que lleva el viento" (v.4), el hombre es dichoso sí y solo sí está "enraizado" en la voluntad de Dios y permite que esta le nutra y alimente para poder "dar fruto a su tiempo" (Ska, 2001: 3031).

5 Todas las citas bíblicas aquí empleadas han sido tomadas de: Escuela Bíblica Arqueológica de Jerusalén (2009). 
Asimismo, en la tradición profética, Israel es comúnmente presentado como una viña "arrancada de Egipto" (ver Sal 80,9) cuidadosamente tratada, despedregada y plantada por Dios, de la cual se espera que produzca buenas uvas, que corresponden a las obras de justicia y honradez $z^{6}$; no obstante, en lugar de tales frutos, se producen agraces, representados por la iniquidad y los lamentos: “¡Pues la viña de YHWH Sebaot es la casa de Israel, y los hombres de Judá son su plantío exquisito! Esperaba de ellos justicia, pero brotó iniquidad; esperaba honradez, pero se oyeron lamentos" (Is 5,7). De hecho, el exilio será entendido por los profetas como la destrucción de la viña por no haber producido frutos de justicia (ver Os 10,1; Is 5,1-7; 27,2-5; Jr 2,21; 5,10; 6,9; 12,10; Ez 15,1-8; 17,3-10; 19,1014).

En el Nuevo Testamento, Jesús retomará la imagen de la viña en la parábola de los viñadores homicidas para aludir a la actitud de las autoridades religiosas cuya responsabilidad, como labradores, era "recibir los frutos" pero terminaron por masacrar a los siervos y al hijo del propietario (Mc 12,1-12; Mt 21,33-44; Lc 20,9-19). No es de extrañar, al respecto, que en el Apocalipsis el juicio de las naciones sea representado como una gran vendimia (Ap 14,18-20) ${ }^{7}$.

Con estos precedentes, una de las imágenes más representativas de la comunión de los creyentes en Cristo es la desarrollada en el cuarto evangelio a través de la alegoría de la vid y los sarmientos:

Yo soy la vid verdadera, y mi padre es el viñador. Todo sarmiento que en mí no da fruto lo corta, y todo el que da fruto lo limpia para que dé más fruto (...). Permaneced en mí, como yo en vosotros. Lo mismo que el sarmiento no puede dar fruto por sí mismo, si no permanece en la vid; así tampoco vosotros si no permanecéis en mí. Yo soy la vid; vosotros los sarmientos. El que permanece en mí y yo en él, ese da mucho fruto; porque separados de mí no podéis hacer nada (Jn 15, 1-2.4-5).

Aquí, la condición de posibilidad para producir frutos está expresada en términos de permanencia: Del mismo modo que el Hijo está en el seno del Padre (Jn 1,18) y permanece en el amor del Padre $(15,10)$, y al igual que

\footnotetext{
6 De acuerdo con Muñoz León (2007: 666), “en el frontispicio del Templo de Jerusalén había una hermosa vid para significar a Israel”.

7 En tal vendimia "los racimos que el ángel arroja en el lagar de la ira de Dios representan a los seguidores de la Bestia que impusieron sobre el mundo una tortura que ahora se vuelve contra ellos (...). [Mientras que] la viña y lagar de Cristo produce vino bueno del reino, banquete final de los salvados (Jn 15,1-17), la vida de los adoradores de la Bestia se hace sangre de muerte, asesinato perdurable" (Pikaza, 1999: 177).
} 
el Espíritu que permanece (๕̌ $\mu \varepsilon ı v \varepsilon v)$ en Jesús (1,32-33), la comunidad discipular, como sarmiento, si desea dar fruto abundante, debe permanecer unida a Jesús, la "vid verdadera", y permitir que él, a su vez, permanezca en ella $(15,4)^{8}$. "La rotunda afirmación «separados de mí no podéis hacer nada» es una manera de indicar la necesidad absoluta de la unión con Jesús para la vida del discípulo" (Muñoz León, 2007: 666). Así como la vid comunica continuamente la vida y el alimento al sarmiento y este deja de fructificar y muere cuando deja de recibir la savia vital, la comunión se manifiesta como una relación de interdependencia orgánica entre el discípulo y Jesús y entre Jesús y el Padre (Sarasa Gallego, 2009). No basta simplemente con una relación momentánea o intermitente. Para mantener la vida y producir fruto es indispensable permanecer.

En las cartas joánicas esta comunión con Dios se comprende como la permanencia del creyente en la vida "intra-trinitaria" (si es posible afirmarlo de este modo ya en la tradición neotestamentaria) en la medida en que este permanezca unido a la comunidad eclesial a través de la confesión de la misma fe y de la vivencia del mutuo amor: "Lo que hemos visto y oído, os lo anunciamos, para que también vosotros estéis en comunión con nosotros. Y nosotros estamos en comunión con el Padre y con su Hijo Jesucristo" (1Jn 1,3). En consecuencia, esta relación comunional "comienza como comunión con el Padre y el Hijo $(1,3.6)$ por un permanecer que inicia aquí y se consuma en el más allá (3,2.24; 4,13)" (Hauck, 2002, 349).

Además, estar en comunión con Cristo no depende simplemente de afirmar verbalmente dicha comunión sino de caminar realmente "en la luz" y ello es condición de posibilidad de la mutua unión establecida por la sangre purificadora de Cristo: "Si decimos que estamos en comunión con él, y caminamos en tinieblas, mentimos y no obramos la verdad. Pero si caminamos en la luz, como él mismo está en la luz, estamos en comunión unos con otros, y la sangre de su Hijo Jesús nos purifica de todo pecado" (1Jn1,7). De este modo, de acuerdo con Eichler (1990: 228), dicha comunión,

Sólo se hace posible a través del Hijo de Dios hecho hombre, a través de Jesús. Es operada por el testimonio del Espíritu Santo, que poseen los cristianos (1Jn 2,20.27; 5,10). El que no tiene en él el testimonio del Padre y su palabra no conoce a Dios ni posee la vida eterna (Jn 5,38ss). Pero el que está en relación personal con él, y esto quiere decir en una relación operada por

\footnotetext{
8 No es de extrañar que, en todo el conjunto de la Biblia, la mayor recurrencia del verbo permanecer ( $\mu \varepsilon \dot{v} \omega \omega)$ se registre en el corpus joánico: 33 veces en Jn y 19 en 1 y $2 J n$, lo que lleva a suponer que esta es una categoría fundamental de la comunión en el Cuarto evangelio y la tradición joánica.
} 
el espíritu y que tiene una dimensión histórica, tiene al Padre y posee la vida eterna. Esto también supone confesar la fe (1Jn 4,2.15; 2Jn 7) y permanecer en la recta doctrina ( $2 \mathrm{Jn} 9$ ), así como guardar su palabra y sus mandamientos (1Jn 2,3s).

Manteniendo el motivo vegetal, Pablo entiende que los gentiles que

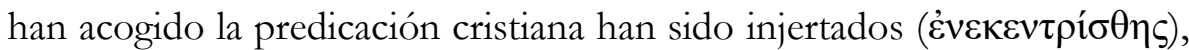
como "ramas de olivo silvestre", en el "olivo cultivado" del judaísmo; es decir que no son poseedores de algo que tenga raíz propia e independiente, sino que, por la gracia de Dios, se hacen partícipes de la elección y las promesas abrahámicas y beben de "la misma savia". De igual modo, el árbol del judaísmo sería enriquecido al verse renovado por este injerto de nuevas ramas de procedencia diversa (Fernández, 2007: 806; Gil Arbiol, 2015: 15):

Y si la raíz es santa también las ramas. Que si algunas ramas fueron desgaja-

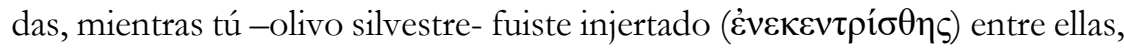
hecho partícipe con ( $\sigma 0 \gamma \kappa o v v \omega v o ̀ \varsigma)$ ellas de la raíz y de la savia del olivo, no te engrías contra las ramas. Y si te engríes, sábete que no eres tú quien sostiene lar raíz, sino la raíz quien te sostiene. Pero dirás: Las ramas fueron desgajadas para que yo fuera injertado. ¡Muy bien! Por su incredulidad fueron desgajadas, mientras tú, por la fe te mantienes. ¡No te engrías!; más bien, teme $(\mathrm{Rm} 11,16 \mathrm{~b}-20)$.

Y mientras que en el Evangelio según Juan, el verbo "permanecer" es la clave de la comunión, en Pablo la comunión estará expresada a través del uso de la preposición "en” (’゙v), siempre en relación con Cristo, como un modo de enfatizar la vida nueva en la que participa todo creyente ${ }^{9}$. De hecho, la condición bautismal será para Pablo el inicio de la comunión con Cristo a través de la participación en su misterio pascual:

¿O es que ignoráis que cuantos fuimos bautizados en Cristo Jesús, fuimos bautizados en su muerte? Fuimos, pues, con él sepultados por el bautismo en la muerte, a fin de que, al igual que Cristo fue resucitado de entre los muertos por medio de la gloria del Padre, así también nosotros vivamos una vida

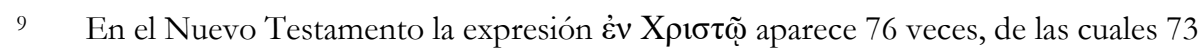
corresponden al corpus paulino: 13 en Rm, 11 en 1Cor, 10 en Filp, 7 en 2Tm, 6 en 2Cor, 6 en Gal, 3 en Col, 3 en 1Tm, 3 en Film y 2 en 1Ti: ver Rm 3,24; 6,3.11.23; 8,1-2.9.1011.39; 9,1; 12,5; 15,17; 16,3.9-10; 1Cor 1,4.30; 3,1; 4,10.15.17; 10,16; 15,18-19.22-23.31; 16,24; 2 Cor 1,21; 2,14.17; 5,17.19; 12,2; Gal 2,4; 2,16-17; 3,14.26-27; 3,28; 5,6; Filp 1,26; 2,1; 3,14; 4,7.13.21; Film 1,8.20.23. 
nueva. Porque si nos hemos hecho una misma cosa con él por una muerte semejante a la suya, también lo seremos por una resurrección semejante $(\mathrm{Rm}$ $3-5)^{10}$.

Es así que la filiación adoptiva propiciada por la vida bautismal elimina la distancia entre el creador y sus criaturas y hace que el creyente llegue a ser "una misma cosa" ( $\sigma u ́ \mu \varphi v \tau o r$, lit. "plantado juntamente") con Cristo $\mathrm{y}$, por consiguiente, de acuerdo con 2P 1,4, partícipe de la naturaleza divina

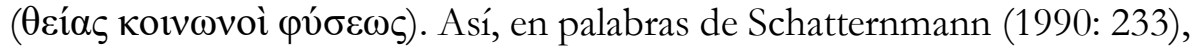
el nuevo ser es "introducido en la muerte de Jesús y en su sepultura, pero también en su resurrección y glorificación. Esto no lleva consigo una anulación de la personalidad ni una fusión de las diferentes personalidades, sino que conduce a una nueva relación con Dios" basada en la transformación total del pecador a una nueva existencia en Cristo.

De igual modo, participar de la salvación es estar en Cristo a través de su Espíritu (ver Rm 8,9). Y, como expresa Eichler (1990: 228), "el tener el espíritu significa, en sentido estricto, un ser-tenido por el espíritu (Rm 8,14). El creyente ya no se pertenece a sí mismo (1Cor 6,19; Cfr. 3,16), es siervo de Cristo (Rm 1,1; 1Cor 7,22)".

1.2. Comunión que es oblativa, unitiva, carismática y ministerial: La organicidad del cuerpo humano como metáfora de la koinonía eclesial

Mientras que la imagen de la corporeidad vegetal enfatiza la relación de permanencia y co-pertenencia que debe existir entre cada una de las partes de la planta y entre esta, la tierra que le aporta el alimento y el labrador/viñador que la cuida y protege, con el fin de dar fruto abundante, a través de la metáfora del cuerpo humano (que parte del principio según el cual el cuerpo individual del creyente es visto como un microcosmos del cuerpo social de la comunidad y este, a su vez, un reflejo del cuerpo de Cristo) (1Cor 12,12-27) (Gil Arbiol, 2010: 179) Pablo ofrece una imagen de la comunión que pone de relieve la complementariedad, la unidad y el servicio recíproco que debe caracterizar a la comunidad, con un cuidado especial por los más débiles.

10 De acuerdo con Borg \& Crossan (2009: 197), "Llegamos a ser uno con Cristo, en Cristo, al ser crucificados con él, muriendo y resucitando con él, participando de su muerte y resurrección. En este sentido, «en Cristo» es una metáfora que expresa una nueva identidad personal y una nueva orientación hacia la vida: el tipo de vida que deriva de un «trasplante de Espíritu». Pero la vida «en Cristo» no se refería solamente ni en primer lugar a una nueva identidad personal para los individuos (...). Para Pablo, la vida «en Cristo» fue siempre un asunto comunitario". 
En primer lugar, el don del propio cuerpo (es decir, de la integralidad de la persona) manifiesta la máxima actitud de latría (en busca de la comunión con Dios) a través de la entrega gratuita y absoluta a los otros (en busca de la comunión con los demás), a imagen del paradigma de toda donación: Jesús que entrega su cuerpo en la cruz: "Os exhorto, pues, hermanos, por la misericordia de Dios, a que ofrezcáis vuestros cuerpos como una víctima viva, santa, agradable a Dios: tal será vuestro culto espiritual" (Rm 12). En tal sentido, De Mingo (2014: 146) comenta que, "el culto que agrada a Dios no consiste en matar animales sobre un altar, sino en ofrecer el propio cuerpo, es decir, la vida concreta de cada uno; los actos de amor que hacemos día a día son el regalo que Dios quiere, no animales muertos sobre un altar".

En segundo lugar, la comunidad de creyentes (es decir, de aquellos que, en virtud del bautismo han optado por ofrecer su cuerpo -su serpara beneficio de muchos, a imagen de Jesús) constituye un solo cuerpo, que tiene muchos miembros y cada uno de ellos, diferente entre sí, sin ser más o menos importante que los demás, ejerce un servicio (ministerio) fundamental suscitado por la presencia del único Espíritu $(12,4-7)$ que se manifiesta de modo distinto en cada uno de ellos para la edificación y pervivencia del cuerpo total:

Como el cuerpo, que siendo uno, tiene muchos miembros, y los miembros, siendo muchos, forman un solo cuerpo, así también Cristo (...). El cuerpo no está compuesto de un miembro, sino de muchos. Si el pie dijera: Como no soy mano, no pertenezco al cuerpo, no por ello dejaría de pertenecer al cuerpo. Si el oído dijera: Como no soy ojo, no pertenezco al cuerpo, no por ello dejaría de pertenecer al cuerpo. Si todo el cuerpo fuera ojo, ¿cómo oiría?; si todo fuera oído, ¿cómo olería? Dios ha dispuesto los miembros en el cuerpo, cada uno como ha querido. Si todo fuera un solo miembro, ¿dónde estaría el cuerpo? Ahora bien, los miembros son muchos, el cuerpo es uno. No puede el ojo decir a la mano: No te necesito; ni la cabeza a los pies: No los necesito. Más aún, los miembros del cuerpo que se consideran más débiles son indispensables, y a los que consideramos menos nobles los rodeamos de más honor. Las partes menos presentables las tratamos con más decencia; ya que las otras no lo necesitan. Dios organizó el cuerpo dando más honor al que menos valía, de modo que no hubiera división en el cuerpo $\mathrm{y}$ todos los miembros se interesaran por igual unos por otros. Si un miembro sufre, sufren con él todos los miembros; si un miembro es honrado, se alegran con él todos los miembros. Ustedes son el cuerpo de Cristo, y cada uno en particular, miembro de ese cuerpo (1Cor 12,12.14-27).

De este modo, la imagen del cuerpo acentúa la dimensión de la comunión al señalar una realidad unitiva lograda por la interacción de partes 
diferentes pero complementarias entre sí. Por ello, Sánchez Bosh (2002: 211) afirma que,

La Iglesia es un solo cuerpo porque es «Cristo» (v.12) y porque el Espíritu la conduce a la unidad (v.13). Pablo deja claro que el cuerpo no es un solo (tipo de) miembro (vv. 14.19.20) y que Dios ha dado una función a cada miembro (v.18). Los distintos miembros se necesitan mutuamente (vv. 21-24a), porque Dios los ha destinado a la unidad (v.24b) y a la colaboración (v.25): a compartir tanto el sufrimiento como la gloria (v.26).

No obstante, las diferencias entre los miembros de esta unidad orgánica no son originadas por los miembros mismos (por sus propios méritos o esfuerzos) sino que son suscitadas carismáticamente por la presencia del Espíritu en cada uno de ellos; lo que implica que ninguno tenga por qué vanagloriarse ni considerarse más que otros. Antes bien, la singularidad de cada uno sólo adquiere sentido en la medida en que sea puesta al servicio de los demás, con un especial cuidado por los más frágiles y débiles, por aquellos que, ante los ojos de la cultura dominante, carecen de valor y aprecio. Como señala la nota al pie de La Biblia de nuestro pueblo (Schökel, 2006: 2180),

[...] los dones y carismas no son cualidades naturales ni fruto del esfuerzo humano ni méritos o privilegios, sino pura gracia y regalo de las tres personas divinas. Además, estos dones no son para uso y usufructo exclusivo de los que los han recibió, sino para el bien de toda la comunidad (...). La imagen de sociedad como «cuerpo organizado» era bastante común en el pensamiento ético de la cultura griega. Se usaba, sin embargo, para reforzar el «statu quo», es decir, la superioridad y el dominio de unos sobre otros. Al aplicar esa imagen a la comunidad cristiana, Pablo intenta justamente lo contrario: desmantelar cualquier estructura de dominio que margine a los miembros más débiles y vulnerables, o que les quite el protagonismo y los reduzca simplemente a «oír» y «callar».

En el mismo sentido, Foulkes (2007: 856) afirma que,

Cuando enfatiza la diversidad entre las partes del cuerpo Pablo utiliza esta multiformidad como una estrategia de resistencia ante cualquier imposición de parte de líderes que promocionen unos dones en detrimento de otros. Cuando habla de la unidad del cuerpo, constituido de muchos miembros (vv. 12-13), lo hace para señalar que las desigualdades han de ser superadas, no reforzadas. En los vv. 15-20 Pablo toma en cuenta la tendencia a la autodescalificación que manifiestan las personas más humildes o con dones pocos llamativos; confirma su valor y afirma su lugar en la comunidad (...). 
De nuevo el ejemplo del cuerpo se cita para mostrar que la comunidad cristiana se forja con base en otros principios: el aprecio por las partes «más débiles», reconociendo que son esenciales, no superfluas (v.22), y el respeto por los que «parecen menos dignos», sabiendo que Dios los ha honrado (vv. 23-24). De hecho, todos forman parte de una mutualidad: lo que afecta a unos, para bien o para mal, debe afectar a todos (vv. 25-26) (...). La visión de Pablo para esta asociación de desiguales (cfr. 1,26-28) es que llegue a ser una comunidad en que las personas de más poder e influencia hagan suya la situación de los «menos honrosos» (v.23), identificándose con ellos de tal forma que ya no los consideren ajenos y por tanto susceptibles de ser ignorados o menospreciados.

En efecto, la metáfora corporal paulina no se limita a presentar una abstracción teórica de lo que debe ser la comunidad de los creyentes, sino que se traduce en unas prácticas concretas que van desde el partir el pan hasta la solidaridad, la inclusión de los excluidos, y el cuidado de los demás (especialmente los más vulnerables). Así, lo indica De Mingo (2014, 130),

Los primeros cristianos se comprendieron a sí mismos como una comunidad que encarnaba sobre la tierra el Cuerpo de Cristo, para ofrecer en su nombre un espacio de hospitalidad y comunión. Esta comunión no consiste, ante todo, en el acuerdo sobre unos ideales comunes o una doctrina compartida; acontece a un nivel más corporal: Compartir el pan, cantar juntos (...), acciones que transforman lo que somos a través de prácticas que implican a toda la persona.

\section{LA UNIÓN ESPONSAL COMO PARADIGMA DE COMUNIÓN}

\subsection{Comunión que supone la igualdad y la diferencia}

Estableciendo un puente temático y antropológico entre la realidad del cuerpo y la esponsalidad, Juan Pablo II (1980: 1), remitiéndose al segundo relato de la creación (Gn 2,4-25), expresa que,

La revelación y, al mismo tiempo, el descubrimiento originario del significado «esponsalicio» del cuerpo, consiste en presentar al hombre, varón y mujer, en toda la realidad y verdad de su cuerpo y sexo («estaban desnudos»), y a la vez, en la plena libertad de toda coacción del cuerpo y del sexo. De esto parece dar testimonio la desnudez de los progenitores, interiormente libres de la vergüenza. Se puede decir que, creados por el Amor, esto es, dotados en su ser de masculinidad y feminidad, ambos están «desnudos», porque son libres de la misma libertad del don. Esta libertad está precisamente en la base del significado esponsalicio del cuerpo. El cuerpo humano, con su sexo, y con su masculinidad y feminidad, visto en el misterio mismo 
de la creación, es no sólo fuente de fecundidad y de procreación, como en todo el orden natural, sino que incluye desde «el principio» el atributo «esponsalicio», es decir, la capacidad de expresar el amor: ese amor precisamente en el que el hombre-persona se convierte en don y -mediante este don- realiza el sentido mismo de su ser y existir.

En efecto, resulta significativo que la primera experiencia de comunión encontrada en la Biblia corresponde al encuentro amoroso y unitivo de la primera pareja humana: "Por eso deja el hombre a su padre y a su madre y se une a su mujer, y se hacen una sola carne" (Gn 2,24). En tal sentido, Francisco (2016: n.13) indica que,

El verbo «unirse» en el original hebreo indica una estrecha sintonía, una adhesión física e interior, hasta el punto que se utiliza para describir la unión con Dios: «Mi alma está unida a ti» (Sal 63,9), canta el orante. Se evoca así la unión matrimonial no solamente en su dimensión sexual y corpórea sino también en su donación voluntaria de amor. El fruto de esta unión es «ser una sola carne», sea en el abrazo físico, sea en la unión de los corazones y de las vidas y, quizá, en el hijo que nacerá de los dos, el cual llevará en sí, uniéndolas no sólo genéticamente sino también espiritualmente, las dos «carnes».

Pero dicha unión sólo es posible a partir del reconocimiento gozoso de la existencia y la semejanza del otro/de la otra: “¡Esta sí que es hueso de mis huesos y carne de mi carne!" (Gn 2,23b). "Son las primeras palabras que pronuncia el primer hombre en la Biblia: voz del esposo, voz gozosa" (Schökel, 1999: 40). Aquí, el reconocimiento del otro/de la otra y de su semejanza con respecto a la propia realidad personal se convierte en condición de posibilidad de la propia existencia, de la unión recíproca y hasta de una condición humana auténtica, tanto más cuando dicha unión es la realización plena de la semejanza del ser humano con el creador expresada en el texto por la imagen de la diferenciación sexual: "Creó, pues, Dios al ser humano a imagen suya, a imagen de Dios le creó, macho y hembra los creó" (Gn 1,27). Así pues, la semejanza con Dios, comunión íntima de las divinas personas diferentes entre sí (según la revelación cristiana), se manifiesta en la pareja humana por la comunión establecida al interior de esta, no a pesar sino gracias a sus diferencias constitutivas. No resulta extraño, entonces, constatar la afirmación de Francisco (2016: n.10): "Sorprendentemente, la «imagen de Dios» tiene como paralelo explicativo precisamente a la pareja «hombre y mujer»". De este modo, es posible afirmar que la comunión, dinamizada necesariamente por el amor, involucra el reconocimiento tanto de la igualdad como de la diferencia y, por tal motivo, anticipa la novedad neotestamentaria de la participación de la criatura humana en la naturaleza divina que es esencialmente comunional. 


\subsection{Comunión que engendra vida}

No obstante, el fruto o finalidad última de esta unión modélica no es simplemente la comunión en sí y por sí sino la generación y el cuidado de nueva vida. Es por ello que el primer mandamiento que Dios dirige a la pareja humana en el primer relato de la creación es "Sed fecundos y multiplicaos y henchid la tierra y sometedla" (Gn 1,28a). Y en el segundo relato, aún a pesar de la transgresión del jardín, la vida es vista como una bendición de Dios para la pareja, que, aunque se ha excluido de su condición paradisiaca, aún no ha perdido su comunión recíproca vital: "Conoció el hombre a Eva, su mujer, la cual concibió y dio a luz a Caín, y dijo: 'He adquirido un varón con el favor de YHWH"' (Gn 4,1). Al respecto, Francisco (2016: n.11) señala:

La pareja que ama y genera la vida es la verdadera «escultura» viviente -no aquella de piedra u oro que el Decálogo prohíbe-, capaz de manifestar al Dios creador y salvador. Por eso el amor fecundo llega a ser el símbolo de las realidades íntimas de Dios (cf. Gn 1,28; 9,7; 17,2-5.16; 28,3; 35,11; 48,34). A esto se debe el que la narración del Génesis, siguiendo la llamada «tradición sacerdotal», esté atravesada por varias secuencias genealógicas (cf. 4,17$22.25-26 ; 5 ; 10 ; 11,10-32 ; 25,1-4.12-17.19-26 ; 36)$, porque la capacidad de generar de la pareja humana es el camino por el cual se desarrolla la historia de la salvación. Bajo esta luz, la relación fecunda de la pareja se vuelve una imagen para descubrir y describir el misterio de Dios, fundamental en la visión cristiana de la Trinidad que contempla en Dios al Padre, al Hijo y al Espíritu de amor. El Dios Trinidad es comunión de amor y la familia es su reflejo viviente (...). La familia no es pues algo ajeno a la misma esencia divina. Este aspecto trinitario de la pareja tiene una nueva representación en la teología paulina cuando el Apóstol la relaciona con el «misterio» de la unión entre Cristo y la Iglesia (cf. Ef 5,21-33).

Esta estrecha relación entre la comunión y la vida será un motivo fundamental en la tradición joánica en que la unión de Jesús con el Padre constituye el modelo de la unión entre los creyentes (ver Jn 17,21) con la finalidad de tener vida, una "vida en abundancia" (Jn 10, 10). La vida es, por tanto, el fruto auténtico y el criterio de reconocimiento de toda auténtica comunión.

\subsection{Comunión que se hace alianza y capacita para la fidelidad}

Por otra parte, el lenguaje veterotestamentario de la alianza entre Dios y el pueblo, si bien conserva el principio de subordinación diferenciada y, por tanto, no llega a ser considerado plenamente comunional, ha recurrido 
a la imagen esponsal para expresar la relación amorosa entre Dios y el pueblo". En efecto, la expresión "Yo os haré mi pueblo, y seré vuestro Dios" (Ex 6,7a) no sólo evoca un acuerdo de mutua pertenencia, al estilo de los pactos de vasallaje entre los pueblos conquistados y los imperios invasores, sino que principalmente recuerda los términos empleados entre los amantes y enamorados: "Yo soy para mi amado y mi amado es para mí” (Ct 2,16a; 6,3a; 7,11). Es así que el profetismo de la época monárquica caracterizará la relación entre Dios y el pueblo en términos nupciales: Dios es el esposo siempre fiel, Israel (o Judá, según el caso) es la esposa que ha caído en infidelidad ${ }^{12}$.

La idolatría, que quebranta el primer mandamiento, es interpretada como adulterio o prostitución, los ídolos son vistos como amantes y el modo como los oráculos expresan el sentir de Dios refleja el lenguaje del esposo despechado, engañado y ofendido, pero sorpresivamente dispuesto a perdonar y a conquistar de nuevo el corazón de su amada (ver Os 2; Ez 16) (Sicre, 1989: 53-77): "Por eso voy a seducirla: La llevaré al desierto y hablaré a su corazón (...). Y ella responderá allí como en los días de su juventud (...). Yo te desposaré conmigo para siempre; te desposaré conmigo en justicia y en derecho, en amor y en compasión, te des-

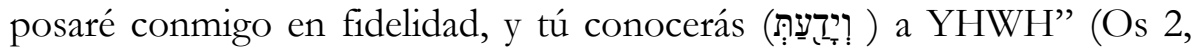
16.17b.21-22).

En este pasaje, el verbo hebreo ${ }^{\top}$ ?, que comúnmente se traduce como "conocer, saber, darse cuenta, enterarse, reconocer, elegir" (Ortiz Valdivieso, 2001: 67), es empleado, tanto aquí como en otros textos veterotestamentarios (ver, por ejemplo, Gn 4,1.17.25; 19.5.8.33.35; 24,16; 38,16), para señalar la relación sexual, lo que supondría que el lenguaje nupcial para referirse a la Alianza establecida entre Dios y el pueblo sería una de las mayores expresiones comunionales de la $\mathrm{TaNaK}$ al homologar la intimidad de la pareja humana con la intimidad que puede alcanzarse entre el ser humano y Dios.

Es así que,

Por la alianza toma Dios a su cargo la existencia de Israel, toma como suyos sus intereses (Ex 23,22), quiere que haya un encuentro (Am 3,2) y trata de ganarse su corazón (Os 2,16). Este designio de comunión, resorte de la

11 No puede desconocerse que en el mundo cultural en que se plasmó el texto sagrado la cultura patriarcal supone una relación de subordinación de la mujer con respecto al varón. Como el pueblo con respecto a Dios, ella le debe al varón obediencia, fidelidad y fecundidad (Barrado Fernández, 2012: 35-42).

12 Es evidente el trasfondo patriarcal de la imagen que supone que quien propende al adulterio es, por lo general, la mujer, quien, con su actuar, pondría en riesgo el honor del marido. 
alianza, se revela en el aparato con que Dios rodea su iniciativa: sus largos coloquios con Moisés (Ex 19,20; 24,12-18), el nombre de «la tienda de reunión» en que se encuentra con él (33,7-11) (Sesboüé \& Guillet, 2001: 174).

En tal sentido, para Ezequiel y Jeremías, los profetas que experimentaron la desolación ocasionada por el destierro de Judá en Babilonia y que han leído tal destrucción como la consecuencia de la infidelidad del pueblo a la Alianza del Sinaí, la Nueva Alianza será prefigurada en términos de transformación del corazón de Israel por parte de YHWH, el siempre y único fiel, en que este capacita a aquel para permanecer conforme a la Torah, no ya por sus propios esfuerzos o méritos (pues ya ha demostrado que ello no es humanamente posible) sino por acción de la gracia que viene de Dios: "Esta será la alianza que yo pacte con la casa de Israel, después de aquellos días -oráculo de YHWH-: pondré mi Ley en su interior y sobre sus corazones la escribiré, y yo seré su Dios y ellos serán mi pueblo" (Jr 31,33 TM). De este modo la Ley ya no será más externa al sujeto, plasmada simplemente en tablas de piedra, esta será inscrita en el corazón mismo del pueblo, haciéndole capaz de recordar que ha sido graciosamente elegido y rescatado por Dios y de elegir libremente a Dios por encima de los dioses de los demás pueblos (Casas Ramírez, 2013: 133-134).

\subsection{Comunión que congrega y reúne a los dispersos}

Ezequiel, además del motivo de la transformación del corazón de piedra (el material en que fue plasmada la primera alianza) en carne (la realidad viviente y frágil de la criatura), añade un signo de comunión que caracterizará la santificación del nombre de Dios en medio de las naciones, que expresará el final del exilio por medio del regreso a Sion y que plasmará la expectativa escatológica de Israel nuevamente constituido como comunidad de YHWH. Este signo consiste en la congregación del Israel dispersado en torno al Señor:

Sí, yo los he alejado entre las naciones, y los he dispersado por los países, pero yo he sido un santuario para ellos, por poco tiempo, en los países adonde han ido. Por eso yo os recogeré de en medio de los pueblos, os congregaré de los países en los que habéis sido dispersados y os daré la tierra de Israel (...). Yo les daré un solo corazón y pondré en ellos un espíritu nuevo: quitaré de su carne el corazón de piedra y les daré un corazón de carne, para que caminen según mis preceptos, observen mis normas y las pongan en práctica, y así sean mi pueblo y yo sea su Dios (Ez 11, 16-17.1920). 
Esta reunión no sólo se realiza juntando a los dispersos entre sí sino también reuniéndoles a ellos con el Señor. De hecho, la tradición rabínica describe el distanciamiento de Dios por causa del pecado y la injusticia, pero también su regreso a la unión con su pueblo a través de la entrega de un libro en que la Alianza se materializa en términos esponsales, el Cantar de los Cantares:

Cuando Adán pecó, Dios subió al primer cielo alejándose de la tierra y de los hombres. Cuando Caín pecó, subió al segundo cielo. Con la generación de Enoc, subió al tercer cielo; con la del diluvio, al cuarto; con la generación de Babel, al quinto; con la esclavitud de Egipto, subió al sexto y al séptimo cielo, el último y más lejano de la tierra (Génesis Rabbá 19,13). Pero Dios volvió a la tierra el día en que se le dio a Israel el Cantar de los Cantares (Zohar Terumá 143-144a) (citado por Ravasi, 1998: 11-12).

En efecto, al regreso del exilio hubo que enfrentar el conflicto entre los israelitas de la golah (exiliados que retornaron al país) y los los 'amba'artetz. ("el pueblo del país"). "El centro del conflicto estaba en la disputa por el derecho a la propiedad de la tierra. El 'pueblo del país' decía que la tierra era de ellos, porque la habían trabajado durante cincuenta años. Los exiliados decían que Yahvé había ido con ellos al exilio y que había prometido devolverlos a la tierra" (Anderson \& Gorgulho, 2007: 831). Es en tal contexto en que se realiza la redacción final del Cantar de los cantares y, a través de dicha composición, en que la unión de los amantes es el eje conductor,

Se expresa un proyecto de restauración del pueblo en la figura de la Mujer, la cual se convierte en el foco de integración del campo (las aldeas de la provincia de Judá) y de la Ciudad de Jerusalén. Es la restauración de un pueblo de hermanos que no viven en la servidumbre y mucho menos oprimen a sus hermanos (...). La unión de los hermanos en el Jardín constituye el foco y el contenido central de la restauración de las casas campesinas y de todo el pueblo (Anderson \& Gorgulho, 2007: 832).

De este modo, el amor de la pareja vuelve a ser referente modélico para el pueblo, esta vez por su capacidad reconciliadora. Desde tal perspectiva, la restauración sólo es posible en la medida en que los que regresan del destierro y los que se quedaron en la tierra se reconozcan mutuamente como miembros de un único pueblo cuyo amor debe estar por encima de las circunstancias que les dividieron. Sólo así, por medio de la unión de los dispersos, se podrá renovar la Alianza y reconstruir la nación.

En esta misma línea, la tradición joánica entenderá la muerte de Jesús como el acontecimiento que lleva a plenitud esta renovación de la Alianza 
al atraer a todos hacia sí (Jn 12,32) y "reunir a los hijos de Dios dispersos" (Jn 11,52), posibilitando, de este modo, la comunión definitiva entre los creyentes. A su modo, las tradiciones paulina y deuteropaulina entenderán que en la cruz Dios ha reconciliado el mundo consigo por la sangre de Cristo de tal modo que la Alianza, de carácter nupcial entre Dios e Israel, se hace extensiva a los no judíos, eliminando cualquier distinción o separación no solo entre judíos y gentiles sino también entre esclavos y libres, entre hombres y mujeres. Esta realidad en la que Cristo constituye el principio de unidad podrá, finalmente, garantizar una relación de comunión plena: "No hay judío ni griego; no hay esclavo ni libre; no hay hombre ni mujer; porque todos sois uno en Cristo Jesús" (Gal 3,28; ver también Rm 1,16; 2,9; 10,12; Col 3,11). De acuerdo con De Mingo (2014: 141),

Esta frase expresa la convicción paulina de que en Cristo finalmente se ha revelado el amor universal de Dios, que nos abraza a cada uno en nuestra humanidad desnuda de etiquetas y que nos lleva a reconocer en ella la posibilidad de una comunión que va más allá de toda diferencia. Las jerarquías socialmente establecidas en los ámbitos religioso (judío-gentil), económicosocial (esclavo-libre) y de género (varón-mujer) son superadas por Cristo (...). Nadie puede reclamar privilegios ante un Dios que ha actuado así.

De este modo, Jesus el Cristo, Hijo de Dios “nacido de mujer” (Gal 4,4) - es decir, partícipe al mismo tiempo tanto de la naturaleza divina como de la naturaleza humana-, rompe cualquier separación entre Dios y las creaturas y al interior de estas mismas para posibilitar la participación plena de estas en la vida de aquel.

\subsection{Comunión que salva}

Así, superada por Cristo y en Cristo cualquier subordinación o diferenciación entre las criaturas y entre estas y Dios, como cerrando el arco interpretativo iniciado en el Génesis, la unión esponsal, que constituye un único cuerpo por el amor, vuelve a ser presentada como modelo de comunión plena mediante la afirmación de la reciprocidad del amor y la entrega entre la pareja que transparenta la comunión y la entrega de Cristo, el novio/esposo, por la Iglesia, novia/esposa en cuanto que esta encarna la plenitud del Israel renovado (ver Mc 2,19-20; Mt 9,15; 25,1.5.10; Lc 5,34-35; Jn3,29; 1Cor 7,3-5a.10.16; Ef 5,25-28). De esta manera la comunión esponsal adquiere una dimensión soteriológica en cuanto que el marido se convierte en mediación salvífica de su esposa y la esposa del marido: "Pues, ¿qué sabes tú, mujer, si salvarás a tu marido? Y ¿qué sabes tú, marido, si salvarás a tu mujer?” (1Cor 7,16). 
En tal perspectiva, la salvación será entendida en términos comunionales como un acto recíproco de continuo volcamiento y vaciamiento hacia la persona amada en que la salida de sí (la ruptura de los límites del yo) abre el camino de la trascendencia y, por tanto, permite la participación en la dinámica auto-donativa de Dios. De esta manera, se anticipa y degusta la Vida Eterna en la medida en que se vive como aquel que es Eterno, es decir, dándose sin medida. Tal es así que la última imagen presentada en la Biblia, que recoge el culmen de las expectativas escatológicas del Israel Renovado, corresponde a las nupcias entre Cristo, el Cordero degollado, y la Jerusalén mesiánica. Por este motivo, la salvación definitiva se expresa como la comunión plena entre el cielo y la tierra, entre Dios y su creación, representada mediante un motivo esponsal en que fidelidad martirial de la ciudad/novia Jerusalén se presentará como el antitipo de la idolatría y opresión efectuadas por la ciudad/prostituta Babilonia: "Alegrémonos y regocijémonos y démosle gloria, porque han llegado las bodas del Cordero, y su Esposa se ha engalanado y se le ha concedido vestirse de lino deslumbrante de blancura -el lino son las buenas acciones de los santos- (...). Dichosos los invitados al banquete de bodas del Cordero" (Ap 19,7-9) (Contreras Molina, 1998: 11-98). Al respecto, Vanni (2011: 185-186) anota que,

Las bodas del Cordero son colocadas en paralelo con la realización definitiva del Reino. Y es a nivel del reino realizado donde surge la reciprocidad nupcial entre Cristo y su pueblo en la situación definitiva propia de la nueva Jerusalén (...). [Así,] la historia de la salvación es considerada como la historia de un amor indecible, que encuentra su consumación en la celebración de las bodas.

Sobre este mismo sentido, Mora (2007: 93) sostiene que,

La comunión tiene como máxima expresión una maravillosa liturgia en la que convergen cielo y tierra, Antiguo y Nuevo Testamento, historia y eternidad, en torno de Cristo, con una sentida expresión universalista, en todo lo cual la Iglesia, comunidad de los santos, es presentada como novia, esposa y ciudad, en donde Dios y el Cordero habitan, en donde no hay noche, en donde hay puertas abiertas, de donde brota la vida y, en fin, en la cual, la invocación que el Espíritu y la comunidad hacen, «iven, Señor Jesús», es respondida por el mismo Cristo: «iSí, vengo pronto!». 


\section{EL COMPARTIR LA MESA COMO REALIZACIÓN DE TODA COMUNIÓN}

3.1. Comunión que rompe fronteras sociales y anula discriminaciones

En primer lugar, el hecho de que el hombre esté obligado a comer día tras día, teniendo en cuenta que aquello de lo que se alimenta es externo a sí mismo, le lleva a comprender que él no tiene la vida en sí mismo. "Así, cuando el hombre bíblico come, no realiza una actividad meramente nutricional, sino que en ella descubre su condición contingente, es una criatura". En efecto, "toda tentación para el hombre de creerse omnipotente, de creer que posee la vida en sí mismo, de creerse eterno, se rompe cada vez que se sienta a la mesa”. (Barrios Tao, 2008: 351-352)

En segundo lugar, no es posible reducir la acción de comer a un simple ejercicio fisiológico de alimentación y digestión. Por lo general, se come en compañía de otros y es dicha compañía la que establece los vínculos identitarios y valorativos al interior de un grupo humano. Como señala Bernabé Ubieta (2004: 177):

El compartir la mesa ha tenido siempre un significado muy profundo. Comer con alguien era compartir más cosas que los meros alimentos; significaba estrechar lazos, reforzar vínculos e identidades, compartir la esperanza. Negarse a compartirla era poner barreras, excluir o rechazar. De este hondo significado antropológico del comer juntos surge el símbolo judío del reino de Dios como un banquete, el banquete escatológico.

Por su parte, Klosinski (1996: 85) sostiene que:

Compartir la comida es una transacción que implica una serie de obligaciones mutuas, y que inaugura un complejo interrelacionado de interdependencia y reciprocidad. Además, la capacidad que tiene la comida de simbolizar esas relaciones, así como de definir las líneas divisorias que separaran a los distintos grupos, constituye una de las particularidades más sobresalientes (...). El acto de comer es un tipo de comportamiento que simboliza la existencia de unos sentimientos y una relación; concilia los diversos grados de status y de poder, y traza las líneas divisorias que marcan la identidad de un grupo.

De este modo, la comensalía supone la comunión de intereses, de expectativas, de fe y de vida y se convierte en una réplica, a nivel microcósmico, del orden social establecido. Ello explica por qué en el mundo bíblico se previene en contra del sentarse a la mesa con los impíos (Sal 1,1) y se critica a Jesús por comer con publicanos y pecadores (Mc 2,15-17; Mt 9,10-13; Lc 5,29-32; 15,1-2). De hecho, esta comensalía abierta de Jesús, 
en que se materializa simbólicamente el Reinado de Dios anunciado por él, supone una novedad en la dinámica de comunión puesto que produce una ruptura de las fronteras étnicas (pues ofrece el pan tanto a judíos como a no judíos ${ }^{13}$ ), morales (pues come con publicanos y pecadores e invita al banquete tanto a "malos y buenos", según Mt 22,10) y cultuales (pues come con excluidos debido a su condición impureza ritual $\left.{ }^{14}\right)$ que estratificaban y discriminaban su entorno social (García Arenas, 2015; Aguirre Monasterio, 1994; Aleixandre Parra, 2009; Barrios Tao, 2007). Así, la comunión representada por la mesa compartida de Jesús supone una disposición de apertura total a todos aquellos estigmatizados, marginados, ignorados y excluidos, anticipando, de este modo, la igualdad que caracteriza a los hijos en el reino del Padre.

3.2. Comunión que es memorial y participación en el misterio pascual de Cristo

En coherencia con la práctica de su maestro, el signo representativo de la comunión en el movimiento de Jesús tiene que ver con la participación en el único pan que es partido y compartido en memoria de Cristo. Por ello, como expresa Guijarro (2017: 585),

En la versión más antigua del ritual eucarístico de las comunidades de Siria, que puede datarse a finales del siglo I, las palabras que se pronuncian sobre el pan y el vino no hacen referencia a la muerte de Jesús, sino a la dispersión de la iglesia, que será congregada en el reino de Dios, del mismo modo que los fragmentos del pan partido, que estaban dispersos por los montes, se han unido para formar el único pan (Did 9,1-5).

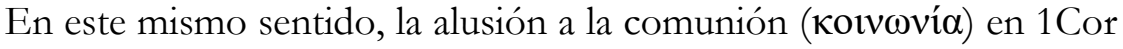
10,16-17 “y, sobre todo, al efecto unificador de dicha comunión, evoca la bendición de Didajé, pero con una connotación nueva: ahora se trata de la comunión con Cristo" (Guijarro, 2017: 586). De este modo, partir y compartir el pan "significa la participación en el cuerpo y la sangre de Cristo y con ello el hacerse uno con Cristo glorificado" (Schatternmann, 1990: 232). De igual manera, "en Jn, el pan eucarístico es el alimento indispensable de la comunión permanente con Cristo (Jn 6,56)" (Mora, 2007: 89). Como señala Guijarro (2017: 586), "en estos dos pasajes [el de 1Cor y el de Jn 6] lo que se subraya no es el sentido salvífico de la muerte de Jesús, sino la comunión con él".

$13 \mathrm{Al}$ respecto, ver la cuestión del "pan de los hijos dado a los perros" y "las dos multiplicaciones de panes” en Mc 6,30-8,10.

14 Ver Mc 14,3; Mt 26,6; Lc 7,34-50. 
Al respecto, Hauck (2002: 349) considera que,

La comunión de la Cena del Señor es importante como expresión destacada de la comunión con Cristo (1Cor 10,16ss). Para Pablo, los banquetes sacrificiales denotan la comunión divina (vv.18.20). Quienes comparten la Cena son compañeros de Cristo; por eso deben rehuir los banquetes idolátricos ${ }^{15}$. Al tomar del pan y del vino comparten con Cristo en una comunión interna que comporta la bendición del perdón obtenido por su muerte.

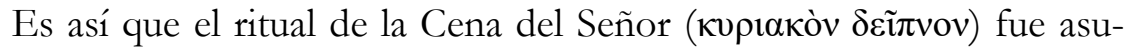
mido desde el temprano inicio de la comunidad discipular como el símbolo por excelencia de comunión entre los creyentes y entre estos con Cristo a través del cual hacen memoria de su muerte, anticipan su regreso ("Siempre que coman este pan y beban esta copa, proclamarán la muerte del Señor hasta que vuelva", en 1Cor 11,26) y participan de su cuerpo ("La copa de bendición que bendecimos, ¿no es comunión con la sangre de Cristo? El pan que partimos, ¿no es comunión con el cuerpo de Cristo? Uno es el pan y uno es el cuerpo que todos formamos porque todos compartimos el único pan”, en 1Cor 10,16-17). De este modo, en un mismo gesto comunional se entrecruzan tres dimensiones de connotaciones teológicas y temporales: el memorial, en referencia al pasado ${ }^{16}$; la escatología, en referencia al futuro; y la participación en el cuerpo de Cristo, como referencia a la realidad actual de la comunidad celebrante.

Asimismo, resulta significativo que las palabras y los gestos de Jesús en la Cena fueron asumidos como fórmulas casi fijas, y de ello dan cuenta los relatos de Mt 26,26-29; Mc 14,22-25; Lc 22,15-20 y 1Cor 11,23-26: Jesús toma el pan, pronuncia la bendición/da gracias, lo parte y lo reparte

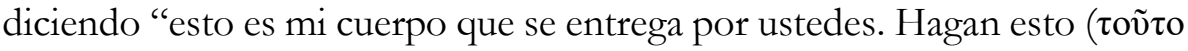

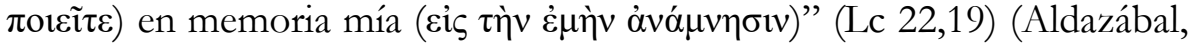
2000: 49-79). Esto supone que el creyente entra en comunión con Cristo al hacer memoria (’่vó $\mu \nu \eta \sigma ı)$ de él comiendo el pan, que es su cuerpo, y,

15 De hecho, "la persona entra en comunión con los poderes a quienes se ofrecen los sacrificios" (Hainz, 2001: 2366). Por ello, si es posible entrar en comunión con Cristo, también se puede entrar en comunión con los ídolos y demonios (1Cor 10,20), por lo que sentarse en la mesa de los ídolos es entrar en comunión con ellos, si se les confiere una existencia real.

16 Por ello, "Cristo no sólo establece comunión mediante la participación en su cuerpo (y sangre), sino también mediante la participación en sus sufrimientos (ver Filp 3,10) (...). En consonancia con ello está la esperanza en la futura comunión con Cristo mediante la participación en su gloria (cfr. 1P 5,1)" (Hainz, 2001: 2366). De hecho, la comunidad se siente unida a la pasión de Cristo también a través de sus propias luchas y sufrimientos. Por esta razón, "las persecuciones sufridas juntos hacen la unidad de los corazones (2Cor 1,7; Heb 10,33; 1P 4,13)” (Schatternmann, 1990: 231). 
en coherencia "haciendo esto", es decir, como Jesús, partiendo y repartiendo su propio cuerpo para que otros tengan vida. De este modo, la sacramentalidad del rito eucarístico se transparenta en la cotidianidad de una vida "encaristizada"; es decir, en la que la propia entrega y auto-donación del creyente conduce a que todos evoquen, hagan memoria, de la entrega y auto-donación de Jesús.

\subsection{De la comunión de mesa a la comunión de vida y de bienes}

Lo dicho supone que no es posible entrar en plena comunión con Cristo si no se está en plena comunión con cada uno de los miembros de su cuerpo y ello es puesto en evidencia en 1Cor 11,17-34 en que Pablo reprocha a los corintios que celebren la Cena del Señor en medio de divisiones y despreciando o ignorando a los más pobres, débiles y marginados (Mora, 2007: 92). Es así que comer el pan y beber "la copa del Señor indignamente" (v. 27a) es hacerlo pasando por alto la unidad, la justicia y el volcamiento especial que debe existir hacia los más pequeños y últimos; por ello, por despreciar el "cuerpo de Cristo" en sus miembros más débiles, es "pecado contra el cuerpo y la sangre del Señor" (v.27b). En tal sentido, como indica Mora (2007: 89), "la comunión supone puesta en común, es decir, comunidad de vida y por tanto de bienes materiales"17.

En efecto, la mesa común adquiere su concreción tangible en la comunión en la doctrina, en los bienes y en la oración ${ }^{18}$ : "Acudían asiduamente a la enseñanza de los apóstoles, a la comunión, a la fracción del pan

17 Por su parte, Borg \& Crossan (2009: 211-212) opinan que "las palabras sobre la participación «de un modo indigno en la cena del Señor se han entendido en el sentido de un estado indigno de arrepentimiento, así como «sin discernir el cuerpo» se ha interpretado como no percatarse de la presencia real de Cristo en el pan y en el vino. Pero en el contexto de Pablo se dice algo mucho más simple y al mismo tiempo más importante: «discernir el cuerpo» se refiere a la comunidad como el cuerpo de Cristo. El modo en que se celebraba la cena del Señor en Corinto negaba la igualdad «en Cristo», la vida en el cuerpo y el Espíritu de Cristo. En su lugar, se mantenía el abismo entre ricos y pobres y la vida en Cristo se adaptaba a la normalidad de este mundo. En cambio, «en Cristo», todos deben estar en la misma mesa, todos comen la misma comida (...). En el seno de la comunidad, todos son iguales y deberían tener lo mismo, pues se trata de una comida compartida. Todos deben tener lo suficiente. Ésta es la cena del Señor”.

18 Este ideal de vida, aunque con un sentido distinto, era ya conocido en el judaísmo de la época segundo Templo, especialmente por las prácticas de la comunidad de Qumrán. Al respecto, Schatternmann (1990: 231) constata que "según Josefo (Bell. II, 119-161) y Filón (Q.P.I caps. 12-13), la vida en común de los esenios se basaba en la idea de igualdad entre todos sus miembros. Esto lo atestiguan de una forma impactante los testimonios propios de la comunidad de Qumrán. A todos sus miembros se les exigía la entrega de sus bienes. Cada miembro había de poner todas sus propiedades a disposición de la comunidad. Aquí el motivo capital no era tanto el ideal de la comunidad fraternal 
y a las oraciones" $\left(\right.$ Hch 2,42 ${ }^{19}$. Dos capítulos adelante el relato lucano añade:

La multitud de los creyentes no tenía sino un solo corazón y una sola alma. Nadie llamaba suyos a sus bienes, sino que todo era común entre ellos. Los apóstoles daban testimonio con gran poder de la resurrección del Señor Jesús. Y gozaban todos de gran simpatía. No había entre ellos ningún necesitado, porque todos los que poseían campos o casas los vendían, traían el importe de la venta, y lo ponían a los pies de los apóstoles, y se repartía a cada uno según su necesidad (Hch 4,32-34).

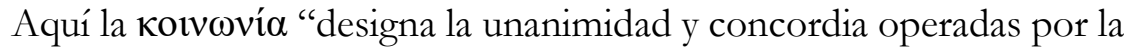
acción del espíritu. El individuo era totalmente sostenido por la comunidad" (Schatternmann, 1990: 232). Por tal motivo, en palabras del mismo autor:

[...] este comunismo religioso basado en el amor» de la primitiva comunidad era consecuencia de un amor carismático, pero tenía como supuesto la permanencia de la propiedad privada, así como la voluntariedad de la ofrenda y de la ayuda al necesitado (...). [Además, esta vivencia] se intensificó ante la espera creciente de la inminencia del fin" (Schatternmann, 1990: 231).

de bienes (como ocurría en Grecia), sino la idea de que el dinero lleva consigo el pecado, pues el dinero es «propiedad de la iniquidad» y es impuro, y, por este motivo, el esenio prescinde de su propiedad privada".

19 De acuerdo con Aldazábal (2000: 21-22), se trata aquí de un programa de vida comunitaria: “a) La enseñanza («didaché») de los apóstoles se entiende como la prolongación más sistemática de la evangelización inicial o «kerigma» (...). b) La comunión («koinonia») parece que aquí no hay que entenderla meramente como una comida en común o una colecta benéfica, ni tampoco exclusivamente como la unión eclesial de fe con los apóstoles o el compartir los bienes, sino como algo global: la unión comunitaria en la misma fe, en torno a Cristo, que lleva a signos externos como la celebración en común («epi to auto») y el compartir los bienes en un clima de fraternidad, aunque esto no implica necesariamente vivir en común o compartir obligatoriamente los bienes materiales. c) Las oraciones («proseuchai») serían seguramente ya oración cristiana, pero también se ve que los primeros discípulos seguían fieles a las oraciones heredadas, sobre todo los salmos, que varias veces se nombran en Hch aplicados a Cristo y a la nueva era de la salvación; asimismo todavía seguían fieles a las oraciones de la sinagoga y del templo. d) La fracción del pan («klais tou artou»), expresión que viene de las comidas judías, sobre todo la pascual, porque su primer gesto es precisamente que el padre de familia toma en sus manos el pan y con una bendición a Dios lo parte para los suyos. Para los cristianos parece que este gesto adquirió muy pronto un sentido específico y dio el nombre a su celebración principal; no sólo a su primer gesto, sino a toda la comida sagrada, entendida ya en su referencia al cuerpo y la sangre de Cristo". 
Concreción y materialización de este ideal comunional fue el proyecto paulino en favor de la colecta de Jerusalén. De hecho, Pablo recurre al

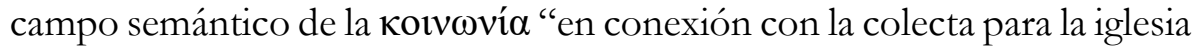
de Jerusalén, la cual da una forma definida a la comunión entre las dos partes del cristianismo ( $\mathrm{Gal}$ 2,9; Rm 15,26). La colecta tiene la significación de una comunión en el servicio $(2$ Cor 8,4$)$ en un compartir sincero y bien dispuesto (2Cor 9,13)" (Hauck, 2002: 349). En el mismo sentido, Hauck (2002) afirma que la comunión con Cristo significa comunión con los otros cristianos en una coparticipación de fe (Flm 17) y de servicio (2Cor $8,23)$. Puesto que los cristianos gentiles comparten las mismas bendiciones que los cristianos judíos, deben compartir con ellos sus bienes materiales (Rm 15,27; 12,13). Como anota Hainz (2001: 2364 y 2367):

La reciprocidad de las relaciones de comunión designadas por el campo léxico notvavía, la acentúa Pablo especialmente en la descripción de las relaciones de sus comunidades con la comunidad madre de Jerusalén y con él, que es su apóstol fundador. En Rm 15,27 Pablo hace ver claramente que esas relaciones de comunión son fundamentalmente relaciones de deuda y

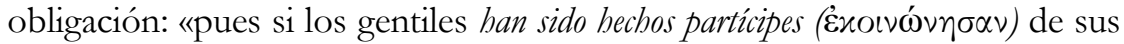
[=de los miembros de la comunidad de Jerusalén] bienes espirituales (el evangelio, la fe, la salvación), entonces son deudores y están obligados a prestarles también a ellos un servicio en las cosas materiales» (...). Según Gal 2,9, Pablo y las autoridades reconocidas en la comunidad primitiva le dieron «la mano de la comunión». El apretón de manos pretendía confirmar con un gesto la comunión existente y expresar la voluntad de que la comunión siguiera siendo eficaz. La comunión sellada tenía su base en la participación común en la proclamación del evangelio que -al menos en principio- era un solo evangelio, y debía hallar su expresión visible en la colecta acordada (cf Gal 2,10). Según 2 Cor 8-9, la colecta es una aportación a la comunión de unas comunidades con otras y particularmente con la de Jerusalén. La colecta es un servicio a la comunidad madre, servicio por el cual (como demostración de la voluntad de comunión) los cristianos de Jerusalén alabarán a Dios $(9,3)$. Así, pues, la colecta es una concreción de la existente relación de comunión y deuda en la cual se hallan las comunidades cristianas gentiles con respecto a la comunidad madre de Jerusalén.

\section{CONCLUSIONES}

Es innegable que el motivo de la comunión es uno de los aspectos fundamentales de la revelación cristiana. Este expresa la común y recíproca participación en la vida, los sufrimientos, los valores e ideales al interior de un grupo humano. Pero, comprendida desde el ámbito de la fe, la comunión se extiende a la posibilidad de que la común-unión criatural 
participe, por la gracia, de la naturaleza misma de la común-unión divina trinitaria, siendo su reflejo y sacramento tangible. La unión en el amor, por el amor y para el amor, constituye, así, el camino y fin de toda criatura, el principio y fundamento de toda realidad, el criterio de verificación de la fe y de la praxis cristiana.

De este modo, y como aporte de la teología bíblica a la reflexión sistemática, se encontró que, en el corpus neotestamentario las imágenes y símbolos comunionales ofrecidos por la tradición veterotestamentarias adquieren su punto climático gracias a la novedad de Jesucristo quien, con su anuncio del Reinado de Dios, su crucifixión y resurrección, rompe cualquier desemejanza entre Dios y las criaturas, haciendo posible, de este modo, el proyecto de una auténtica comunión.

Tales imágenes son, en primer lugar, la unidad orgánica del cuerpo (vegetal y humano). Al respecto, mientras que la organicidad vegetal, imagen de la relación vital entre Dios e Israel y Jesús y los creyentes, expresa una comunión que es arraigo, permanencia y fructificación, la organicidad del cuerpo humano, metáfora de la koinonía eclesial, expresa una comunión que es oblativa, unitiva, carismática y ministerial, con un especial cuidado y valoración por los más débiles y pequeños.

La segunda imagen comunional corresponde a la unión esponsal; esta expresa una comunión que supone la igualdad y la diferencia, que engendra vida, que se hace alianza y capacita para la fidelidad, que congrega y reúne a los dispersos y que salva.

Finalmente, la comunión se manifiesta también a través del gesto del compartir de mesa puesto que allí, a partir de la constatación de la propia contingencia, se expresa una comunión que rompe fronteras sociales y anula discriminaciones, que es memorial y participación en el misterio pascual de Cristo y que, como consecuencia, implica una opción por la justicia, la equidad y la unidad solidaria y colaborativa entre las comunidades creyentes.

\section{REFERENCIAS}

-Aguirre Monasterio, R. (1994). La mesa compartida: Estudios del NT desde las ciencias sociales. Santander: Sal Terrae.

-Albado, O. et al. (2016). Jesucristo, Pan de Vida, comunión fraterna. Revista Teología, 53(120), 9-20.

-Aldazábal, J. (2000). La Eucaristía. Barcelona: Centre de Pastoral Litúrgica.

-Aleixandre Parra, D. (2009). Relatos desde la mesa compartida: Aproximación bíblica y catequética a la Eucaristía. Madrid: CCS. 
-Anderson, A.F. \& Gorgulho, G. (2007). Cantar de los cantares. En A. Levoratti. Comentario Bíblico Latinoamericano: Antiguo Testamento (vol. II, pp. 825-833). Estella: Verbo Divino.

-Andiñach, P. (2014). El Dios que está: Teología del Antiguo Testamento. Estella: Verbo Divino.

-Bandstra, B. (2004). Reading the Old Testament: An Introduction to the Hebrew Bible. Belmont: Thomson-Wadsworth.

-Barrado Fernández, P. (2012). La Biblia en su cultura. Madrid: PPC.

-Barrios Tao, H. (2007). La comunión de mesa: Semántica, narrativa, retórica, desde Lucas. Bogotá: Pontificia Universidad Javeriana- Facultad de Teología.

-Barrios Tao, H. (2008). Comida, mesa y banquete: de la Primera a la Segunda Alianza. Theologica Xaveriana, (166), 347-380.

-Barrios, P. (2013). Los rostros de la comunión: Una propuesta sistemática a partir de la teología de Yves M.-J. Congar. Revista Teología, 50(111), 95-115.

-Bernabé Ubieta, C. (2004). El Dios de Jesús: De la santidad a la misericordia. En R. López Rosas, Comer, beber y alegrarse: Estudios biblicos en honor de Raúl Duarte Castillo. (pp. 167-186). México, D.F. Qol - Departamento de Publicaciones de la Universidad Pontificia de México.

-Borg, M. \& Crossan, J. D. (2009). El primer Pablo: La recuperación de un visionario radical. Estella: Verbo Divino.

-Casas Ramírez, J. A. (2013). La conversión como condición de posibilidad del seguimiento del Señor en el Evangelio de Marcos. Cuestiones Teológicas, (93), 127-146.

-Concilio Ecuménico Vaticano II. (2013). Constituciones, Decretos y Declaraciones. Madrid: Biblioteca de Autores Cristianos.

-Congregación para la Doctrina de La Fe. (1992). Carta a los obispos de la Iglesia Católica sobre algunos aspectos de la Iglesia considerada como comunión. Recuperado de http://www.vatican.va/roman_curia/congregations/cfaith/documents/rc_con_cfaith_doc_28051992_communionis-notio_sp.html

-Contreras Molina, F. (1998). La nueva Jerusalén: esperanza de la Iglesia. Ap 21,1-22,5. Salamanca: Sígueme.

-De Mingo, A. (2014). Comunión en la vulnerabilidad. Moralia, (37), 129-147.

-Eichler, J. (1990). Solidaridad ( $\left.\varepsilon_{\chi} \omega\right)$, En L. Coenen, E. Beyreuther y H. Bietenhard (Dirs.), Diccionario Teológico del Nuevo Testamento (vol. IV, pp. 226-229). Salamanca: Sígueme.

-Escuela Bíblica Arqueológica de Jerusalén (Trad. y Edit). (2009). Biblia de Jerusalén. Bilbao: Desclee de Brouwer.

-Fernández, V.M. (2007). Carta a los Romanos. En A. Levoratti (Dir.), Comentario Bíblico Latinoamericano: Nuevo Testamento (pp. 783-822). Estella: Verbo Divino.

-Foulkes, I. (2007). Primera carta a los corintios. En A. Levoratti (Dir). Comentario Bíblico Latinoamericano: Nuevo Testamento (pp. 823-864). Estella: Verbo Divino.

-Francisco (2016). Exhortación apostólica postsinodal Amoris Laetitia. Bogotá: San Pablo. 
-García Arenas, P. A. (2015). Las comidas de Jesús. En C. E. Román Hernández (Comp.), Jesús histórico: Aproximaciones temáticas (pp. 93-123). Bogotá: Pontificia Universidad Javeriana.

-Gil Arbiol, C. (2010). La primera generación fuera de Palestina. En R. Aguirre Monasterio (Dir.), Así empezó el cristianismo (pp. 139-193). Estella: Verbo Divino.

-Gil Arbiol, C. (2015). Pablo en el naciente cristianismo. Estella: Verbo Divino.

-Guijarro, S. (2017). El sentido de la muerte de Jesús en las palabras de la última cena. En G. Tejerina Arias \& G. Hernández Peludo (Coord.), Glorificatio Dei, Santificatio hominum: Homenaje al Prof. José María de Miguel González̧, OSST (pp. 583-607). Salamanca: Secretariado Trinitario.

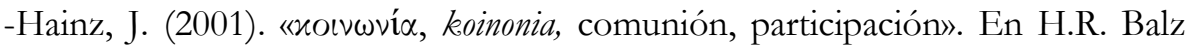
(Dir.), Diccionario Exegético del Nuevo Testamento (vol 2., pp. 2360-2368). Salamanca: Sígueme.

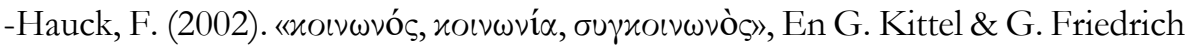
(Dirs.), Compendio del Diccionario Teológico del Nuevo Testamento (pp. 347-350). Grand Rapids: Libros desafío.

-Juan Pablo II (1980). Significado esponsal del cuerpo bumano. Audiencia General del 16 de enero de 1980. Recuperado de https://w2.vatican.va/content/john-paulii/es/audiences/1980/documents/hf_jp-ii_aud_19800116.html).

-Klosinski, L.E. (1996). The Meals in Mark. Ann Arbor: Claremont Graduate School.

-Mateos, J. (1982). Los "Doce" y otros seguidores de Jesús en el Evangelio de Marcos. Madrid: Cristiandad.

-Molac, P. (2009). Purificación y santidad: Una perspectiva de "comunión” según san Gregoria de Nacianzo. Aproximación a partir del discurso 40. Scripta Theologica, (41), 833-842.

-Mora, J.A. (2007). Comunión: Itinerario bíblico y eclesial hacia la V Conferencia. Theologica Xaveriana, (161), 79-106.

-Muñoz León, D. (2007). Evangelio según san Juan. En A. Levoratti (Dir.), Comentario Bíblico Latinoamericano: Nuevo Testamento (pp. 595-688). Estella: Verbo Divino.

-Ortiz Valdivieso, P. (2001). Léxico Hebreo/Arameo-Español - Español-Hebreo/Arameo. Madrid: Sociedades Bíblicas Unidas.

-Pikaza, X. (1999). Apocalipsis. Estella: Navarra.

-Ponce Cuéllar, M. (2011). La Iglesia, misterio de comunión. Valencia: Edicep.

-Ponce Cuéllar, M. (2013). El Señor viene: Escatología. Valencia: Edicep.

-Ravasi, G. (1998). El Cantar de los Cantares. Bogotá: San Pablo.

-Sánchez Bosh, J. (2002). Escritos paulinos. Estella: Verbo Divino.

-Sánchez Cañizares, J. (2014). El fundamento filial de la moral familiar: Hacia la Comunión en la Filiación. Scripta Theologica, (46), 279-305.

-Sarasa Gallego, L. G. (2009). La subsidiariedad en el Evangelio de Juan. Theologica Xaveriana, (168), 471-489. 


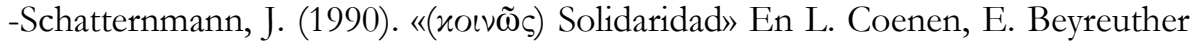
\& H. Bietenhard (Dirs.), Diccionario Teológico del Nuevo Testamento (vol. IV, pp. 229-233). Salamanca: Sígueme.

-Schökel, A. (1999). Símbolos matrimoniales en la Biblia. Navarra: Verbo Divino.

-Schökel, A. (Trad.). (2006). La Biblia de Nuestro Pueblo. Bilbao: Mensajero.

-Serreti, M. (1997). La naturaleza comunional de la persona humana como principio de socialidad: de la comunión divina a la sociedad de los hombres. En A. Sarmiento (Dir.). XV II Simposio Internacional de Teología de la Universidad de Navarra (pp. 791-801). Navarra: Servicio de publicaciones de la Universidad de Navarra.

-Sesboüé, D. \& Guillet, J. (2001). Comunión. En X. Léon-Dufour (Dir.). Vocabulario de Teología Bíblica (pp. 173-175). Barcelona: Herder.

-Sicre, J.L. (1989). La idolatría y los profetas. En, J.M. Castillo \& J.A. Estrada. La Iglesia y los profetas (pp. 53-77). Córdoba: El Almendro.

-Ska, J.L. (2001). Introducción a la lectura del Pentateuco: Claves para la interpretación de los cinco primeros libros de la Biblia. Estella: Verbo Divino.

-Tejerina Arias, G. (2015). La gracia y la comunión. Ensayo de eclesiología fundamental. Salamanca: Secretariado Trinitario.

-V Conferencia General del Episcopado Latinoamericano y del Caribe (2010). Documento de Aparecida. CELAM: Bogotá.

-Vanni, U. (2011). El Hombre del Apocalipsis: Una visión antropológica, moral y espiritual. Bogotá: San Pablo - Facultad de Teología, Pontificia Universidad Javeriana. -Zizioulas, I. (2009). Comunión y alteridad: Persona e Iglesia. Salamanca: Sígueme.

Sumario: Introducción; 1. La unidad orgánica del cuerpo (vegetal y humano) como símbolo de comunión; 1.1. Comunión que es arraigo, permanencia y fructificación: La organicidad vegetal como imagen de la relación vital entre Dios e Israel; 1.2. Comunión que es oblativa, unitiva, carismática y ministerial: La organicidad del cuerpo humano como metáfora de la koinonía eclesial; 2. La unión esponsal como paradigma de comunión; 2.1. Comunión que supone la igualdad y la diferencia; 2.2. Comunión que engendra vida; 2.3. Comunión que se hace alianza y capacita para la fidelidad; 2.4. Comunión que congrega y reúne a los dispersos; 2.5. Comunión que salva; 3 . El compartir de mesa como realización de toda comunión; 3.1. Comunión que rompe fronteras sociales y anula discriminaciones; 3.2. Comunión que es memorial y participación en el misterio pascual de Cristo; 3.3. De la comunión de mesa a la comunión de vida y de bienes; Conclusiones; Referencias. 